\title{
Reflections of the Changing Education System According to the Views of School Managers: Turkey Sample
}

\author{
H. Gulhan Orhan-Karsak
}

Department of Education Sciences, Science-Literature Faculty, Kirklareli University, Turkey

Copyright $\bigcirc 2017$ by authors, all rights reserved. Authors agree that this article remains permanently open access under the terms of the Creative Commons Attribution License 4.0 International License

\begin{abstract}
To adapt to the advances of the era, the economic, technological, social and cultural competition continues growing rapidly between the world countries. The main way to adapt this competition is to improve the quality of human edification, in the other words to change education system. As one of the developing Asian countries in the world, Turkey wants to reach advanced development like other powerful countries in the world. So Turkey is one of the sample countries in the world that changes the education system in recent days. The aim of this research is to examine the opinions of school managers with respect to their views on the practical implications of the legal changes to the 4+4+4 new education system in Turkey. Qualitative methods were used for this phenomenon study and the participants were 34 school managers from several private and official institutions in Kirklareli city in Turkey. School managers were taken from utilizing eight semi-structured open-ended questions according to law which is about new education system to get their experiences. Data were collected in writing in fifty minutes and were given personal numbers. Data were analyzed via NVivo 10 and were created categories and themes. Findings were presented with tables and mind maps. The findings were coded into themes and presented with mind maps and tables. The results show that managers were attempting to implement the $4+4+4$ new education system in Turkey accordance with the legal provisions. There are, however, some problems in doing so and the analysis of the issues they raised, has resulted in a number of recommendations.
\end{abstract}

Keywords Compulsory Education, Primary School, Middle School, Education Law, Changing Education System, Education Reforms

\section{Introduction}

From the past to the present, nations have been striving to increase the educational level of their societies and individuals have been striving to increase their own level of education. Individuals' efforts to improve their standard of education level have goals such as t0 desire for achieving their objectives, the ability to generate income and to provide intrinsic satisfaction. In other words, their extrinsic goal is to achieve higher acceptance in society. National efforts to improve educational levels also have a number of goals, such as to increase the quantity and quality of the labour force that is available to serve the community and in so doing, to raise the level of development in that society and thus to attain a position in the international area. There is no doubt that parents contribute greatly to the realization of the goals of their children. Yet the contribution of the education system is much more significant when it aims to achieve both individual and national goals in an orderly and planned manner. This is why, over centuries nations have continually attempted to organize their education systems to achieve their changing and developing goals.

As Comertler et al. [8] stated, it is known that as the individual level of education increases, the crime rate is reduced in society and it results in an increase in the level of income. This balance between decrease and increase is one of the key points in the development of a nation. However, as the individual acquisition of professional skills increase, a society increases its productive power and is also expected to have a say in the international production market. For this reason, as Wielemans [32] stated, educational policies are extremely important for shaping the future of societies. Education policy is an important factor that affects the development of a society and educational policies are a high priority political task in many countries. This concerns all citizens and affects parents and children's perspectives on life. The changes in educational policies are important decisions in lifelong learning.

Therefore, there are increasing changes in educational systems together with changes in technology, economy, and social life, impacted by globalization. As Sahlberg [27] discussed, policies and educational strategies bring forward educational reforms that create new realities by establishing structures that allow for evaluations, classifications, and comparisons of national and regional educational systems. 
Today, educational reforms in different countries have created synergetic educational policies due to unlimited information flow and information transfer. These policies have brought similar responsibilities, values and characteristic properties to educational systems. As Christensen et al. [7] discussed, in our global world, the purpose of schools is to improve the skills and capacities of students and to shape their manners by encouraging them to develop multiple perspectives and to think differently. In this regard, in order to increase development of communities and to train a much better qualified labor force for this purpose, the competition between countries to bring educational systems forward still continues. For this purpose, as Torney-Purta et al. [31] discussed, many countries have found the solution to spread problems globally, such as increasing population, unemployment, migration, lingual and religious grouping, and tendency of violence, in modernizing and improving their educational systems.

Another factor that supports bringing educational systems forward is developing technology. Simply putting new technologies in front of students does not encourage learning tasks. Many countries have been reviewing and modernizing their systems through new projects in order to unify education technologies with educational programs that fit student characteristics [28].

At the same time, another factor that affects the need for change and modernization of educational systems is economic growth. Quality education not only increases average income and productivity, but also lowers the possibility of social problems appearing that may be harmful for economic growth. In this context, the race for development between countries also speeds up educational modernization. Many widespread educational reforms are being put in place in order to immediately increase labor productivity and support economic growth through expanding and improving education. Thus, with the changing educational systems, the aim is to continue the economic race by bringing higher quality knowledge and abilities in order to achieve economic development demanded by our age. Accordingly, in order to support their economic growth, countries of today need a flexible educational system that contains a strong communication network, that is creative enough to allow deep collaborations and sharing opinions freely, that can take risks without fear [27].

Modern globalization process speeds up changes in educational policies and consequent applications of scientific, social, political and cultural changes as well as economic and technological growth. This situation demands education practitioners and policy makers to take competition plans of global power, new global trends, personal and social needs of students into account while establishing educational systems [17].

In summary, in order to be able to adapt to changes brought by globalization, the aim is to define and shape the character and qualifications of the new generation through educational systems. However, in many countries, the ability of today's schools to provide an education that can satisfy the needs of the future generations has been in question. The awareness that the level of education given in schools is no longer suitable to the requirements of our age has been increasing. Countries that realize this situation and face these realities resort to making new regulations in their system of education [3].

In this context, France, in 2015, has decided to lighten the heavy language program in schools by lowering the Latin and antique Greek courses for middle school students aged 11-15, and aimed to enrich classic culture and by doing so lower the gap between students in regions of lower and higher economic strength. By correlating student performance with socio-economic levels of the families, it has been detected that kids coming from immigrant families often drop out of school. Therefore, changes in the system have been considered in order to provide an education better suited to immigrant students. In addition, establishing wider play areas and interdisciplinary modules that will be organized by the teachers has been aimed [13].

Similarly, in Spain, innovations in the educational system have been made in 2013 for middle school students, due to high failure and dropout rates, low profile technical education, lack of external assessment and low levels of school autonomy. These innovations can be listed as, increasing the impact of school principals to increase autonomy in schools; introducing 6-10 year olds to external assessment before middle school to increase success, and to share these assessment results with the families and schools to provide information; simplifying and making education more flexible by putting more emphasis into information and communication technologies, foreign languages and instrumental proficiencies [6].

In Poland, a country that has one of the best educational systems according to 2012 OECD data, instead of 8 years of primary education followed by 4 years of middle school or 3 years of technical training, $6+3+3$ model has been introduced in the 1999 educational reform, which consists of 6 years of primary school followed by a 3 year gymnasium with theoretical and scientific classes, and another 3 years of specialized education (specialized lyceum) or 2 years of technical education. General examinations have been put into place after primary school and gymnasium. With the system changes, innovations in school boards and inspection methods, educational methods and core curriculum, assessment and examination system, and school financing have been planned and an increase in teacher salaries through identifying teacher proficiencies required for the new system has been aimed [18].

In Finland, which is another country that is highly spoken of its success in education, several innovations have been considered as part of the government's structural policy program and after seeing a decrease in the latest PISA scores. It has been decided that the school hours and the purpose of high middle school classes be restructured, a core program to 
be prepared, and all regional programs to be reorganized by putting the core program at the center and these programs to be put into effect as August 2016. With this program, the aim is to improve educational methods and make them more interactive and centered around students, to organize more advanced studies to increase student proficiencies and to differentiate the use of educational environments. Again, planned to go into effect in 2016, it has been decided that financing for middle school and technical education to be restructured, competencies in technical education to be reorganize and free adult education institutions to be formed. In addition, it has been decided in August 2016 that the prices for early childhood education will be based on the income level and the size of the family, the prices taken from families with lower levels of income will be reduced. On the other hand, the prices taken from families with higher levels of income will be increased. With the LUMA program, which is tailored for the scientific education and will run through 2019, the goal is to motivate and inspire students to take science and maths education by employing the latest methods and activities used in science and technology education. In addition, with this program, lifelong learning and improving research-based educational proficiencies of teachers working between early childhood and universities will be supported [15].

In addition to the aforementioned innovations in Europe, Bologna innovations have been made in order to restructure higher education. These innovations have provided opportunities to students in European universities in pursuing studies that require more effort and to finish their studies faster, studying with integrating different disciplines, switching to a different program when they are unhappy in an undergraduate program, and therefore created a healthy competition between many short undergraduate programs. It has been contemplated that these innovations will encourage universities in Europe to compete with higher education systems in UK, US, Canada, Australia, New Zealand, India, Pakistan, and other Asian and Latin American countries [26][10].

When we look at Asia, for example in Japan, plans have been made to change basic educational laws, to administer academic ability surveys nationwide and to improve academic talent by taking necessary precautions, to modernize teacher proficiencies by establishing professional institutions and thereby improving teacher quality. In addition, innovations in providing funds for mandatory educational costs from the national treasury have been made and it has been decided that the national government will support the educational costs of local governments [23].

In Turkey, which is a country acting as a bridge between Asia and Europe, innovations in education are being made since 1924 in order to reach a higher quality education system. Another purpose of these innovations is to increase schooling, which is lower compared to developed countries stated above. Analysis of the schooling rates in Turkey for the 2011-2012 academic year show $30.87 \%$ in the age range of 3 to $5,44.04 \%$ in the age range of 4 to $5,55.69 \%$ in the age range of $5,98.67 \%$ in primary education, $67.37 \%$ in middle education and $35.51 \%$ in higher education [20]. When examining the total schooling rates of countries within European Union, which, as early as 2001, was aiming to reach an ideal cultural and social environment, [32], it can be seen that $73 \%$ of the population under the age of $4,99 \%$ of the population between the ages of 5 and 14 , and $82.1 \%$ of the population between the ages of 15 and 19 had been schooled. One of criterions that Turkey is expected to fulfil in the process of adaptation to European Union is to increase the schooling rate [4]. With objective of national, individual and EU harmonisation, Law No 6287 - named the " $4+4+4$ Law", - was adopted by Grand National Assembly of Turkey National Education, Culture, Youth and Sports Commission on 11 March 2012 (published on 11 April 2012) and came into force in 2012 [29].

As indicated in other researches ([11], [14] [21]), from the initial implementation of the law right up until today, public opinions has been concerned with a number of issues, such as primary school starting age, elective courses, use of common areas by different formal education levels, the $4+4+4$ arrangement of formal education levels, teachers' non-preparedness for the system, the transition to higher education, vocational orientation, and Fatih project. Fatih project in education system of Turkey was initiated to provide equal opportunity in education and training and to enable the use of information technology tools in lessons that will appeal to more sensory organs in the learning-teaching process in order to improve the technology in our schools. The scope of this project is as follows: Increasing the added value of domestic production, previously able to produce products without domestic production, can be made of new technology and research and development activities for products, all schools will place their classrooms, information technology hardware, software, network infrastructure and Internet access capability, e-content, teachers and students will be given an e-book, tablet computer with our country to create a business environment to stimulate the domestic production of domestic firms, the development of young entrepreneurial spirit. Fatih project aims to develop 21st century skills such as the use of technology, effective communication, analytical thinking and problem solving [28].

With this system, the compulsory education system which is applied as $5+3$ continuous 8 years has been started to be applied intermittently as $4+4+4$ and the first 4 years as primary school, the second 4 years as middle school and the third 4 years as high school were organized [19]. The positive and negative aspects of the system were detected in different researches. For example in the study conducted by Demir, Dogan and Pinar (2013), after the separation of elementary school and middle school, they point out that they have survived disciplinary problems due to the coexistence of different age groups before the new system. In addition, Epcacan (2014) expressed in his research findings 
that, after the separated teaching levels, the students felt more secure in the same age groups, the teachers communicated more easily with students and the parents believed that their children are in a safer school environment. As opposed to this positive side, as indicated in Demir's (2013) research, the field teachers such as science and social sciences stated that when they entered the 5th grade classes, they had problems in reaching the students' levels and understanding the 5th grade curriculum compared to the class teachers who were entering the classes before the system. Additionally in Aykac and et al.'s (2014) research, the participants have expressed separated teaching stages and the field teachers who began to enter the courses in $5^{\text {th }}$ grade as the strengths of the $4+4+4$ education system. However, the participants have been described in terms of the system's weaknesses in multiple weaker directions. The most emphasized aspects of the weaknesses were the lack of readiness levels of the pupils, the lack of school buildings, the imposition of obedience, top-down and ideological application, the late start of reading and writing, the increase of course load in the 5th grade, the removal of pre-school education from compulsory education. Also half of the teachers who had participated to the stated research had problems in practice and negative attitudes to the new education system. Furthermore, as indicated in Dogan, Ugurlu and Demir's (2014) research, the participants pointed out that religious elective courses which were organized with the new system provided students with moral development and gave students the ability to control their behaviors and that the management of a school of students who could control their behavior is an advantage for managers. Besides that some findings of the different researches are about Fatih project. As indicated in Pamuk and et al.'s (2013) research, it is found out that providing tablets to the teachers and students with a limited use of internet inside the school and a lack of internet connection outside the school diminishes the interest towards the use of tablets. As participants reported, in-service teacher training programs specifically organized for this project were not effective as much as expected. Opposite of these findings the participants expressed the positive outcomes of the project was the increase of communication and collaboration between teachers and students.

In this regard, given that school managers are in continuous interaction with students, parents, teachers, auxiliary staff and other executives in the school environment and can best sense the pulse of that environment, it is important to gain their opinions regarding the implementation process of the $4+4+4$ education system in order to recommend proposals that might increase the efficiency of the system. Within this context, the aim of this study was to determine the positive and negative effects of the $4+4+4$ law from the perspectives of school managers in the different educational levels. According to this aim, the research questions are as below.

What are school managers' opinions about primary school starting age?

What are school managers' opinions about separating elementary schools into primary and middle schools?

What are school managers' opinions about the regulation of compulsory education?

What are school managers' opinions about gradual transition to compulsory education?

What are school managers' opinions about the diversification of middle schools so as to appeal to different area of occupation?

What are school managers' opinions about teaching elective courses at Middle Schools?

What are school managers' opinions about higher education and university education entrance and placement?

What are school managers' opinions about the Fatih (Movement of Enhancing Opportunities and Improving Technology) Project?

\section{Method}

Phenomenology studies are accomplished in order to define the common meaning of the experiences of a few people related to a phenomenon or a concept [9]. In this regard, because of exploring the experiences of the school managers on the components of new education system in Turkey such as compulsory education, elective courses, integration courses with technology, entrance of higher education, etc. Therefore in this phenomenon study to fathom of these experiences of school managers was intended. The phenomenon study has been selected in order to investigate what, why and how are the similarities and differences between the experiences and in the experiences of every school manager. Wherefore the researcher gives lectures, Kirklareli which is one of the city of Turkey, has been selected. Therefore in this study purposeful sampling was used. This sampling method was followed in order to meet certain predetermined criteria [33]. In this regard the opinions of the school managers were taken from utilizing eight semi structured open-ended questions according to law which is about new education system. Data were collected in writing in fifty minutes and were given personal numbers. Data were analyzed via NVivo 10 and have been created categories and themes. The categories and themes obtained by the analysis were then prepared in the form of tables and logical and hierarchical mind maps, each with its own phenomenon, with using the inspiration 9.2 programme. In addition, discrimination has been tried to be reflected in understanding the phenomenon. Finally, participants' perceptions of the topic were interpreted.

For the internal validity of the study, the processes of collecting, analyzing and interpreting the data are consistent. The research reflects the social realities of the participants who have been involved in the study. Links between the categories has been intensified to increase the internal validity of the study. For the external validity of the study, 
the data sources of the research, the collection of the data and the analysis of the data have been explained. The results of this research are generalizable to similar environments and situations. The data obtained for the internal reliability of the study have been presented to the reader without comment. For the external reliability of the study, the characteristics of the participants, who were the data source of the research, has been clearly presented. Only open identities have not been included. The conceptual framework which has been used in the analysis of the obtained data has been defined. Data collection and analysis processes have been explained.

\section{Participants}

A total of 34 school principals were identified with purposeful sampling and included in the study: 12 from primary schools, 9 from middle schools, 6 from elementary schools, 6 from high schools and 1 from an unspecified-institution. This sampling method was followed in order to meet certain predetermined criteria [33]. Easy accessibility is paid attention as criteria.

The personal characteristics of the participants are presented in Table 1.

Table 1. Personal characteristics of school managers

\begin{tabular}{|c|c|c|c|}
\hline Variables Features & \multicolumn{3}{|c|}{ Frequency (f) Percentage (\%) } \\
\hline \multirow[t]{2}{*}{ Sex } & Male & 29 & 85.29 \\
\hline & Female & 5 & 14.71 \\
\hline \multirow[t]{6}{*}{ Length of service } & $1-5$ & 0 & 0.00 \\
\hline & $6-10$ & 1 & 2.94 \\
\hline & $11-15$ & 6 & 17.24 \\
\hline & $16-20$ & 12 & 35.29 \\
\hline & $21-25$ & 6 & 17.64 \\
\hline & 26 and above & 9 & 26.46 \\
\hline \multirow[t]{5}{*}{ Institution } & Primary school & 12 & 35.29 \\
\hline & Middle School & 9 & 26.47 \\
\hline & Elementary school & 6 & 17.64 \\
\hline & High school & 6 & 17.64 \\
\hline & Unspecified & 1 & 2.94 \\
\hline \multirow[t]{12}{*}{ Field } & School teaching & 16 & 47.05 \\
\hline & Information technologies & 1 & 2.94 \\
\hline & Elementary mathematics & 1 & 2.94 \\
\hline & Religious culture and moral knowledge & 3 & 8.82 \\
\hline & Social studies & 4 & 11.76 \\
\hline & Mathematics & 2 & 5.88 \\
\hline & Turkish & 1 & 2.94 \\
\hline & Physical education & 1 & 2.94 \\
\hline & Science and technology & 1 & 2.94 \\
\hline & History & 1 & 2.94 \\
\hline & Turkish language and literature & 1 & 2.94 \\
\hline & Unspecified & 2 & 5.88 \\
\hline \multirow[t]{3}{*}{ Marital status } & Married & 33 & 97.06 \\
\hline & Single & 0 & 0.00 \\
\hline & Separated & 1 & 2.94 \\
\hline \multirow[t]{2}{*}{ Number of children } & One & 8 & 23.53 \\
\hline & Two & 21 & 61.77 \\
\hline
\end{tabular}


As shown in Table 1, 85.29\% of the school principals who participated in the study were male and $14.71 \%$ were female. With respect to years of service, $2.94 \%$ had 6 to 10 years, $17.64 \%$ had 11 to 15 years of service, $35.29 \%$ had 16 to 20 years of service and $17.64 \%$ had 21 to 25 years of service. In terms of school, $35.29 \%$ worked in primary schools, $26.47 \%$ worked in middle schools, $17.64 \%$ worked in elementary schools, $17.64 \%$ worked in high schools and $2.94 \%$ did not specify the institution in which they worked. Most of them worked in classroom teaching $-47.05 \%$ - and the others worked in different areas. A great majority of them were married $-97.06 \%$ - and most of them had two children, $61.77 \%$ -

The categories and themes generated from the data obtained from the participants in the specified feature are presented in Table 2.

Table 2. Categories and themes

* primary school starting age
- suitability for primary school starting age
- recommendations for primary school starting age
* separating elementary schools into primary and middle schools
* the regulation of compulsory education
* gradual transition to compulsory education
* the diversification of middle schools so as to appeal to different area of
occupation
* teaching elective courses at middle schools
- difficulties of elective courses
- problems about elective courses
- problems of instructional program
. teacher problems
- student problems
- problems about material and classroom
- recommendations about elective courses
* difficulties of higher education entrance and placement
* reflections of Fatih (Movement of Enhancing Opportunities and
Improving Technology) Project

\section{Findings}

\subsection{Opinions about Primary School Starting Age}

By law, compulsory primary education covers children between the ages of 6 and 13 years and it should begin at the end of September in the year when the child reaches 5 years age. As shown in Table 3, 20.59\% of participants thought that the starting age for primary school as stated in the law was suitable, $67.65 \%$ thought it was not suitable and $4 \%$ had no opinion.

Table 3. School managers' opinions regarding suitability for primary school starting age

\begin{tabular}{|c|c|c|}
\hline Opinions & f & $\%$ \\
\hline $\begin{array}{c}\text { Primary school starting age is } \\
\text { suitable. }\end{array}$ & 7 & 20.59 \\
$\begin{array}{c}\text { Primary school starting age is } \\
\text { not suitable. } \\
\text { Impartial }\end{array}$ & 23 & 67.65 \\
\hline
\end{tabular}

Table 4. School managers' recommendations for primary school starting age

\begin{tabular}{|c|c|c|c|}
\hline Opinions & f & $\%$ \\
\hline $\begin{array}{c}60 \text { months old and older } \\
\text { children should enroll in } \\
\text { primary school }\end{array}$ & 7 & 20.59 \\
$\begin{array}{c}72 \text { months old and older } \\
\text { children should enroll in } \\
\text { primary school } \\
\text { Impartial }\end{array}$ & 23 & 67.65 \\
\hline
\end{tabular}

As shown in Table 4, 20.59\% of the school managers stated that children of 60 months and older should enroll in primary school, $67.65 \%$ stated that children should be aged 72 months and older when starting primary school, and $4 \%$ had no opinion.

These findings show that the majority of managers disapprove of the current primary school starting age. Focusing on the fact that families have different levels of income and students are at different levels of physical development, the manager coded as $Y_{1}$ stated that, "Turkey is a country with a wide geography and composed of people with very different income levels. So each student may differ in completing their physical development. In this context, it would be more beneficial for children to start school when they are 72 month old" In a similar manner, emphasizing that children who are 60 months old should begin preschool education because of developmental differences, $\mathrm{Y}_{31}$ said that "children should enroll in preschool education and that due importance should be given to widespread preschool education." One participant, $\mathrm{Y}_{22}$, expressed the opinion that "it would not be positive to move the compulsory primary education age to an earlier time because children would have to start school without completing their normal development. Instead of this, it seems to me that preschool education should be mandatory". This manager supported the view that children in this age group should continue with preschool education.

Managers $Y_{16}$ and $Y_{33}$ pointed to the difficulties experienced in the process of implementation a new school starting age. The manager coded as $\mathrm{Y}_{16}$ expressed the view that "difficulties have been experienced in reducing the compulsory primary school age. Difficulties have also been experienced in the education of children who started school in the first year of its implementation. It would be appropriate for 72 month old children to enroll in the first classes". In a similar vein, $\mathrm{Y}_{33}$ stated that "a better achievement is gained when primary school children start their first class at the age of 72 months. Classroom teachers now complain about difference in children who start school when they have reached 66-months of age. The five to six month age difference results in the creation of different groups levels in the classes. They have experienced difficulties in the implementation process. The parents want their children to attend the first class when they reach 66 months of age". Regarding this situation, $\mathrm{Y}_{32}$ expressed the opinion that "70-72 months old children should attend 
depending on their parents' request. Children under the age of 66 months should not start primary school even though their parents want them to enroll in the school".

\subsection{Opinions about Separating Elementary Schools into Primary and Middle Schools}

Table 5. School managers' opinions about dividing elementary schools into primary school and middle school

\begin{tabular}{|c|c|c|c|}
\hline Opinions & $\mathrm{f}$ & $\%$ & \\
\hline $\begin{array}{c}\text { Elementary schools should } \\
\text { separate into primary school } \\
\text { and middle school. }\end{array}$ & 20 & 58.82 & \\
$\begin{array}{c}\text { Elementary schools should } \\
\text { not divide into primary } \\
\text { school and middle school. } \\
\text { Impartial }\end{array}$ & 1 & 2.94 & \\
\hline
\end{tabular}

As shown in Table 5, 58.82\% of the school managers stated that primary and middle schools should provide education in separate buildings, whereas $2.94 \%$ stated that primary and middle schools should provide education in the same building. A further $38.24 \%$ had no opinion on the matter. The majority of managers indicated that primary and middle institutions must be established in separate buildings. With regard to this situation, $\mathrm{Y}_{1}, \mathrm{Y}_{4}$ and $\mathrm{Y}_{32}$ focused on the age and maturity level of primary and middle school students. $\mathrm{Y}_{1}$ stated that "educational units should never exist together. Students at different age and maturity levels must absolutely not use the same physical space". Additionally, touching on the other problems - especially toileting problems - of students of different ages using the same area, $Y_{2}$ and $Y_{32}$ had a similar opinion and $Y_{32}$ expressed the opinion that "an adolescence student and a primary school age student should never use the same toilet. This was wrong. So many secret and unveiled problems had lived. For example, molestation. Therefore, students of different age groups should be educated in separate buildings. A separate building and play garden should be provided even if it consists of only one room. Transformation must definitely achieve without giving as any pretext."

Voicing the concern that primary and middle schools provide education in the same building, $\mathrm{Y}_{2}$ expressed the opinion that "the problem of absenteeism in primary and middle sectors paved the way for indiscipline. Divesting of teacher's right to mark in the primary schools causes students to get further away from the course seriousness. If what it was thought might come to realize, it was a good project but project waned due to shortage of classrooms, too much changing regulations and passivation of teacher. Retaining the $4+4$ system in the same building may cause deviation from the objective". Similarly, $\mathrm{Y}_{16}$ offered the opinion that "the buildings and gardens of town and village schools that have their primary and middle schools in the same building should separate".

In addition, $\mathrm{Y}_{12}$ expressed the opinion that "the most important negative aspect of the system is that primary and middle school students influence each other negatively.
Therefore, I find it proper to separate the buildings from each other. I have the opinion that transformation is more likely to occur once a suitable physical environment has been provided".

\subsection{Opinions about the Regulation of Compulsory Education}

Table 6. Regulation of compulsory education

\begin{tabular}{|c|c|c|}
\hline Opinions & f & $\%$ \\
\hline $\begin{array}{c}\text { Primary, middle and elementary } \\
\text { schools should arrange as 4+4+4 } \\
\text { Primary, middle and elementary } \\
\text { schools should arrange as 5+3+4 } \\
\text { Primary and middle schools } \\
\text { should arrange as 5+3 }\end{array}$ & 8 & 23.52 \\
$\begin{array}{c}\text { Parents' opinions should be take } \\
\text { into account } \\
\text { Impartial }\end{array}$ & 14 & 14.71 \\
\hline
\end{tabular}

As shown in Table 6, with respect to the regulation of compulsory education, $23.52 \%$ of the school managers stated that the periods of primary, middle and elementary schooling should be arrange as $4+4+4,41.18 \%$ stated that period of primary, middle and elementary schooling should be extended to 12 years of compulsory education as $5+3+4$, $14.71 \%$ also believed that the period should be extended to 12 years of compulsory education but using a $5+3$ formula and $2.94 \%$ stated that parents' opinions should take into account in the arrangement of compulsory education. The remaining $17.65 \%$ of managers had no opinion on the matter.

The majority of managers stated that compulsory education should be for a period of 12 years regulated in $5+3+4$ system. For example, in the opinion of manager $Y_{3}$, "5th class students have congruence problems with field teacher. Attention should be paid to the age of abstract thinking. Compulsory education should be $5+3+4$, with one year of preschool". Likewise, $\mathrm{Y}_{10}$ stated that "Current curriculum forces children to move from the fourth grade to fifth grade. It would be better if the transition takes place within the changes of curriculum. The content of the curriculum should be simplified for these students. In this context, if education system will be reformed as $5+3+4$, this might be better". Similarly, $\mathrm{Y}_{23}$ offered the view that the "education system should be $5+3+4$. Fifth grade students fail to adapt to middle school". Again, $Y_{33}$ held the opinion that "primary-middle-high schools should continue to educate in the form of $5+3+4$. A rapid transition to a $4+4+4$ system occurred without creating the necessary infrastructure and teaching staff and without developing courses and curricular. Students are not ready for the fifth grade as middle school students".

As one of the managers who stated that the compulsory education system should be arranged across 12 years in the form of $4+4+4, \mathrm{Y}_{19}$ offered the opinion. "I deem it suitable to provide academic weight training in the current situation during the second four years. So, the number of course hours in European Union countries and the number of course hours 
in Turkey has evened out in this way. Turkey lost one year before. It seems to me that rumours in the press do not reflect the realities. Now system works well." In a similar manner, $\mathrm{Y}_{24}$ stated that the "transition to the $4+4+4$ education system is a correct change in respect of the way it will affect the children. The transition should not be a fully gradual process but all institutions should simultaneously make the transition from $5+3$ to $4+4+4$ ".

In contrast, some managers expressed the view that compulsory education should be arranged as $5+3-8$ rather than 12 years-and that 8 years of compulsory primary education must continue. Focusing on the emergent problems, $\mathrm{Y}_{30}$ stated that "the student has been difficult to follow after 8th grade since a graduation certificate was not conferred on him/her and an additional burden is placed on following absent students enrolled in an upper school". Stressing that 12-year compulsory primary education is not appropriate for all students and that vocational education should start at the school, $\mathrm{Y}_{15}$ held the opinion that "12-year compulsory primary education is not suitable for all individuals (inclusive education, those with specific learning disability, etc.). I approve an 8-year compulsory phase. Middle schools should not be limited to only İmam Hatip elementary schools. Other middle schools should be considered to open for vocational training". Similarly, regarding this situation, $\mathrm{Y}_{17}$ articulated the view that the "period of compulsory education should be 8 years given our country's education system and level and I am of the opinion that it will be appropriate to transition to 12 -year education once the necessary infrastructure is in place".

Suggesting that the arrangements for compulsory education should be optional, $\mathrm{Y}_{17}$ expressed a different opinion about the benefits that "an optional or a more flexible implementation could bring. The system needs to be adopted by teachers, in particular primary schools teachers, since they received their education in another system". In a similar way, the manager suggested that compulsory education should be abolished. $\mathrm{Y}_{27}$ offered the view that middle education institutions should be optional rather than compulsory. Those who want to study have already attended school. There is no sense in keeping a student who does not want to study after the age of 18 . These children are also disrupting the school order. The abolition of compulsory education would be positive. All should be free to go to school where they want". However, stating that, "I do not approve size criterion regarding building separation" and that the logic behind building separation should be that of planning, $Y_{31}$ did not support the criterion for separating the building.

\subsection{Opinions about Gradual Transition to Compulsory Education}

As shown in Table 7, regarding the gradual transition to compulsory education, $14.71 \%$ of school managers deem it suitable and $20.59 \%$ do not deem it suitable. The majority,
$64.70 \%$, stated that they were impartial. According to law, middle school' students who are with primary school' students in the same buildings or place, they make transition to the separate buildings or place gradually. In this context, some managers stated that many problems arose since those who receive education at the 5th, 6 th, 7 th and 8 th grades of primary education institutions at the publication date of law have completed their educations in these institutions.

Table 7. Gradual transition to compulsory education

\begin{tabular}{|c|c|c|}
\hline Opinions & f & $\%$ \\
\hline $\begin{array}{c}\text { Gradual transition to compulsory } \\
\text { education is suitable. }\end{array}$ & 5 & 14.71 \\
$\begin{array}{c}\text { Gradual transition to compulsory } \\
\text { education is not suitable. } \\
\text { Impartial }\end{array}$ & 7 & 20.59 \\
\hline
\end{tabular}

Regarding this situation, Y-coded managers opined that "staying students attending 5th, 6th, 7th and 8th classes with the primary students in the same schools and make transition gradually to the separate middle schools, leads to many problems. Suddenly more field teachers need arose. Teachers working in these schools have transferred to other schools to become the norm as soon as possible. Assignment teachers who are not in the school's staff, are appointed to these schools. Teachers not having any sense of belonging could not be beneficial to these schools. An implementation has caused thousands of problems".

Similarly, implementing the transition at a specific time was favoured by some managers and $\mathrm{Y}_{8}$ and $\mathrm{Y}_{24}$, respectively, stated that the "transition should be all together, not gradual" and the "transition process should not be completely gradual but it should take place in all institutions at the same time". Stressing that a transformation can happens without preparing the necessary infrastructure, $Y_{12}$ expressed the view that "I am of the opinion that it would be appropriate to occur a complete transformation after an appropriate physical environment for the education has been provided". Assessing this situation in terms of students, $\mathrm{Y}_{31}$ offered the opinion, "I think that students exposed to gradual transition had suffered from it". Despite these views, $\mathrm{Y}_{3}, \mathrm{Y}_{2}$, $\mathrm{Y}_{25}, \mathrm{Y}_{20}$ and $\mathrm{Y}_{11}$ stated that they believed a gradual transition to be more appropriate.

\subsection{Opinions about the Diversification of Middle Schools so as to Appeal to Different Area of Occupation}

Regarding their preference between a four-year compulsory and other programmes in middle schools (consisting of middle schools and Muslim religious sect leader and pulpit preacher middle schools), some managers emphasized the necessity for diversification in a way that would appeal to different professional fields. With respect to this issue, $\mathrm{Y}_{1}$ presented the opinion that "middle schools, together with Muslim religious sect leader and pulpit preacher middle schools, should open as vocational high schools. We deceive ourselves into providing vocational 
education for adults aged $16-17$ at the high school II class. The apprenticeship system has collapsed completely". In the same way, $\mathrm{Y}_{3}$ expressed the view that "Muslim religious sect leader and pulpit preacher middle schools should be subject to vocational high schools".

Emphasizing the importance the orientation of the classroom teacher, $\mathrm{Y}_{8}$ expressed the opinion that "the classroom teacher should act as a guided and his/her decisions should be binding and that this should be the case for middle levels of all high schools. If a student succeeds in numeric fields at primary school, $\mathrm{s} / \mathrm{he}$ should be directed to middle schools that focus on Science High Schools and Anatolian High Schools. Once again, if a student is good at manipulative skills in primary school, he should be directed to the middle of vocational high schools. Likewise if a student succeeds in courses of music and visual arts at primary school, he should be directed to the middle of Fine Arts High Schools". Similarly, $\mathrm{Y}_{15}$ held the opinion that "middle schools must not be confined to Muslim religious sect leader and pulpit preacher middle schools. The opening of other middle schools for vocational training should be considered". $Y_{31}$ supported this by asking the question "Is there any middle school enabling students to choose between different programmes apart from Muslim religious sect leader and pulpit preacher schools? They are not intended for branching out".

\subsection{Opinions about Teaching Elective Courses at Middle Schools and Muslim Religious Sect Leader and Pulpit Preacher Middle Schools}

Some of the managers involved in the study have emphasised that the number of hours of elective courses are greater than expected. Related to this, $\mathrm{Y}_{29}$ stated that the "hours of elective courses should be reduced". $Y_{21}$ agreed, expressing the opinion that "hours of elective courses should be decreased by taking account of schools, teachers and environmental conditions". Placing emphasis on the number of elective courses, $\mathrm{Y}_{18}$ also offered the opinion that the "number of elective courses should be, at most, one (for every class)". Focusing on a reduction in the number of elective courses, $\mathrm{Y}_{14}$ stated that "elective courses should be rescheduled and the pool of elective courses should be narrowed".

Similarly, in stating that the hours for these courses should be reduced or even removed, $\mathrm{Y}_{4}$ stated the opinion that the "hours of elective courses should be reduced and that, ideally, weekly course hours should not exceed 30 in middle schools. There is no its contribution to education. Study time which is seperate from the school time, need to open in place of them by removing. It can considered that 'study time' may be also in the primary schools". $\mathrm{Y}_{7}$ and $\mathrm{Y}_{16}$ also voiced their opinions about the elimination of elective courses. Additionally, $\mathrm{Y}_{16}$ articulated a view in favour of "study time" that "elective courses can open under the name of "study time" by eliminating from the practice".
Focusing on the criteria for selecting elective courses, $\mathrm{Y}_{23}$ stated that "courses are selected without considering the characteristics of the schools, adequate facilities and teacher situations". Stressing that friend preference mainly comes to the forefront in course selection, $\mathrm{Y}_{22}$ voiced the opinion that "problems arise due to numerous course selections regarding elective courses. Problems such as classroom seeking, equipment supply and lack of textbooks may arise. More importantly, students' choice of friend has become important rather than their abilities". In addition, $\mathrm{Y}_{24}$ stated that "confusion in the elective courses should be avoided. Elective courses should be selected according to the parents and environmental conditions. Courses should be organised by teachers" and emphasised that teachers should receive education related to their areas of specialisation in order to increase the efficiency of elective courses. Furthermore, touching on the challenges that elective courses pose and stressing that efficiency decreased because of course selection based on parents' request, $\mathrm{Y}_{30}$ stated that the "selection of elective course and teacher tasking place a heavy burden. It is particularly difficult to ensure students' regular attendance at school. What's more, student's performance and success are low since groups in the elective courses are created by parents' request rather student's abilities".

In addition, it was noted that different managers addressed the problems of not improving the efficiency of elective courses. $\mathrm{Y}_{32}$ addressed the problems of not marking the elective selectives and stated the view that the "courses of Quran and Life of Our Prophet and the science of religion should gather under a single roof and should be taught as a whole, including two hours each year as a course of eight hours. It should be assessed with a mark whichever student selects the course. This mark should be reflefted in the grade point average (GPA)".

Tackling an issue of teachers and textbooks in teaching the elective courses, $\mathrm{Y}_{33}$-coded manager voiced the opinion that the "absence of textbooks for many courses selected in the middle schools caused problems. Furthermore, first not assessing of the elective courses with a mark and then assessing them with mark created complete chaos. The teaching staff of the school should also be considered. $\mathrm{He} / \mathrm{she}$ complained that there was no teacher who would teach the course selected by the student. Therefore, the student frequently had to change his opinion about selecting an elective course".

Some managers stated their opinions that some courses are removed from the list of elective courses and made obligatory. $\mathrm{Y}_{5}$ stated the opinion that some elective courses should be compulsory (for example Quran, the Prophet's life, Basic Religious Knowledge)". On the other hand, $\mathrm{Y}_{34}$ stated that "elective courses of six hours should be reduced to two or three hours and several courses, such as the Prophet's life, the Quran, Basic Religious Knowledge and Intelligent Games, should rank among compulsory ones".

The school managers' views of the difficulties associated with elective courses are shown in Figure 1. 


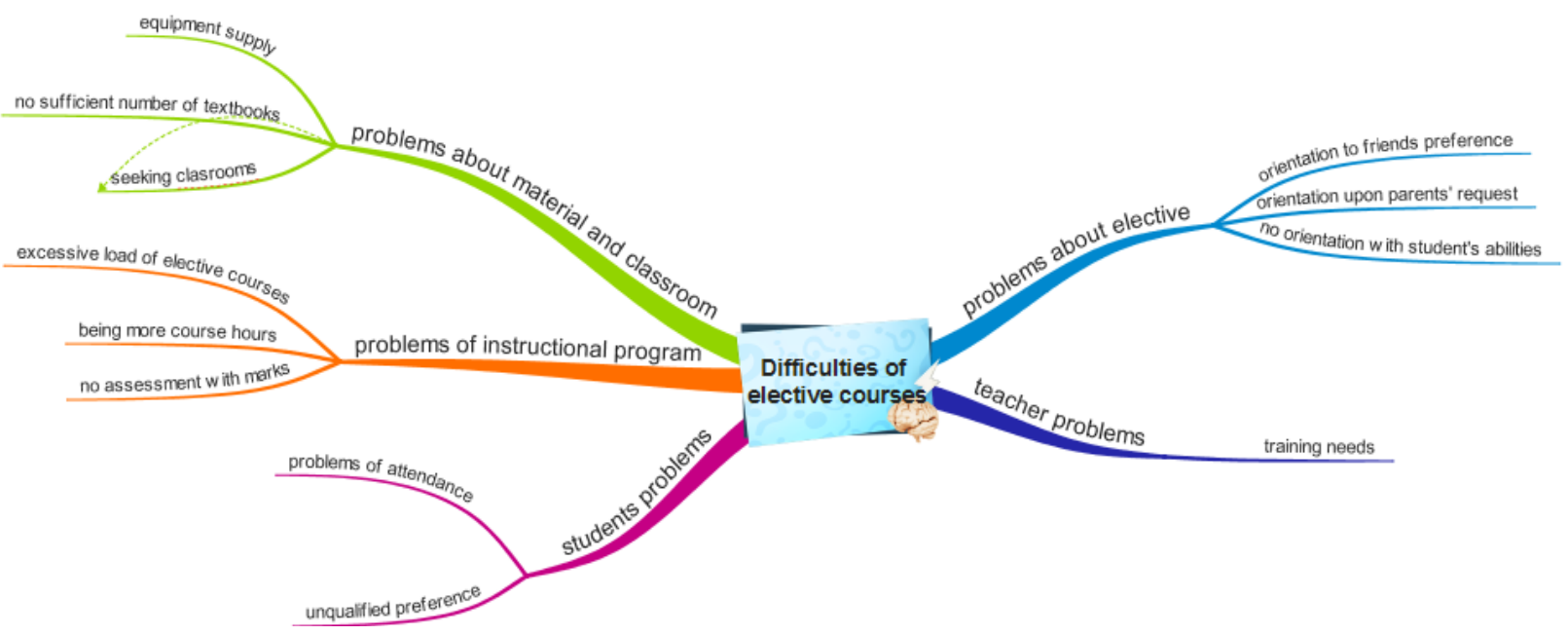

Figure 1. School managers' opinions about the difficulties of elective courses

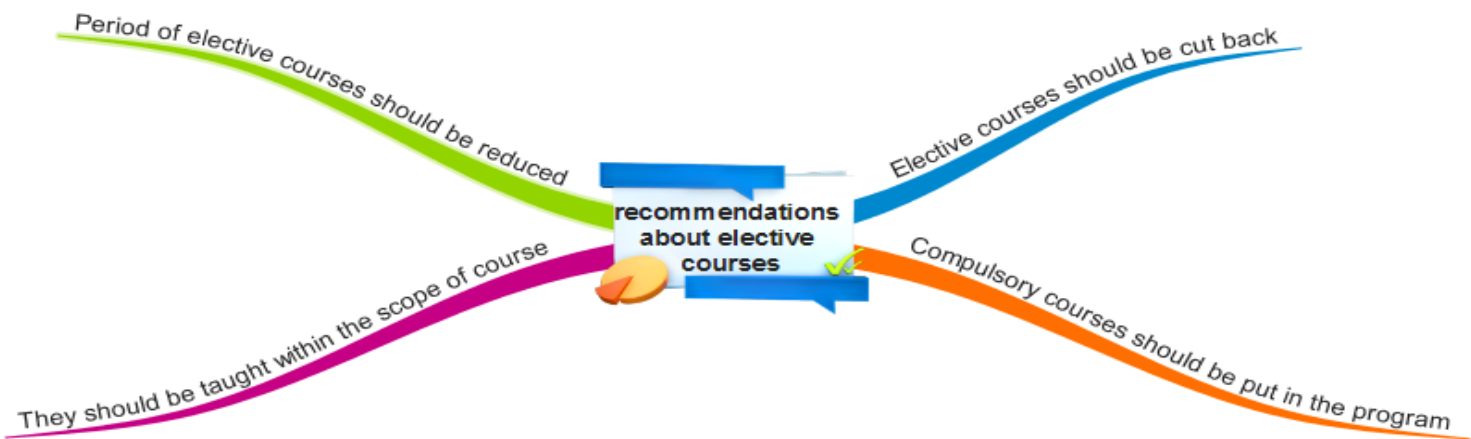

Figure 2. School managers' recommendations about elective courses

The recommendations of school managers about elective courses are shown in Figure 2.

\subsection{Opinions about Higher Education and University Education Entrance and Placement}

The managers expressed different opinions about considerations of the high school grade point average of candidates in the calculation of higher education placement scores. $Y_{1}$ expressed the opinion that "in fact, the equality which the high school grade point average desires to achieve is upset. Schools cannot judge students equally. In particular, private schools have given their students high grades. The school success grade not the diploma grade should be considered in the transition to a university". Similarly, $\mathrm{Y}_{26}$ also stated that the high school grade point average does not ensure equality of opportunity, and expressed the opinion, "I think the high school completion score is not an objective criterion for university placement because I am not of the opinion that the exam system is equal in each school. A good student may be ranked in the middle in an extremely difficult exam in school A. This student might even become the highest ranked in an exam that was taken in school B. This assessment will lead to unjust scoring. Exams taken by high schools are not centralized. If the score for the university entrance exam is valid, this would be fairer in terms of placement".

In the same way, $\mathrm{Y}_{3}$ also highlighted the necessity of the school success point in the calculation and stated that the "schools' success points should be considered. Advantages should be provided to teacher training schools and vocational schools in their own fields". Likewise, $Y_{31}$ stressed the necessity of considering the low school points of vocational technical schools, and also a further factor whereby getting into private university with low points impairs equality of opportunity. The same respondent expressed the opinion that "when we read between the lines in higher education entrance and placement, the state has directed students with low scores to private universities through rules such as $50 \%$ of scholarship to the private sector. The low school points of vocational and technical schools should be addressed".

Supporting similar views and also highlighting the necessity of overlapping middle school subjects and higher education entrance exam subjects, $\mathrm{Y}_{25}$ noted that the "middle school curriculum and the higher education entrance examination' and university entrance examination' subject and questions should overlap in order to ensure equality of opportunity. School points should be given to students in parallel with the type and quality of school where they are received their education. School performance, as well as 
individual success, should be considered. Students who graduated from vocational high schools should be directed to graduate schools in line with the requirements and demands of the private sector. Graduate students should be employed". Furthermore, $\mathrm{Y}_{32}$ expressed the view that an approach similar to the transition from primary to middle education should be implemented. Students becoming national who are country representatives in international competitions in the sports are nice but not enough to place higher education. Additional point should be given to students who are certified and who participate in competitions even though they do not achieve national status. Additional point can be given to them in order to enter higher education institutions related to their field. The difficulties that school managers stated about higher education entrance and placement are shown in Figure 3.

\subsection{Opinions about the Fatih (Movement of Enhancing Opportunities and Improving Technology) Project}

Some of the managers stated that this project has not yet reached their own schools, and its duration appears to be lengthy. For example, $\mathrm{Y}_{32}$ stated that the "period of 15 years had been a very long time but could be reasonable. A lot of money has been spent on the project. In other words, a numerical standard should be laid down when considering the amount of money". Similarly, $\mathrm{Y}_{23}$ stated, "I think the Fatih project is progressing very slowly. It has not reached us yet". Although some managers voiced negative views about tablet computers, they expressed positive opinions about interactive whiteboards. As $\mathrm{Y}_{7}$ noted, "the tablet is unnecessary but interactive whiteboards are extremely helpful", $Y_{1}$ voiced the opinion that "Fatih is a stillborn project. Smart boards are only put into high schools. Its stages in middle school are still incomplete, however. It has never begun to install in vocational schools. The integration of the technology into the course content is still insufficient. Tablets are not associated with the smart boards".

As one who supports the view that the project has reached the high schools but has not reached middle schools, $\mathrm{Y}_{13}$ presented the opinion that the "Fatih project has been established in all of the high schools in our district. It is planned to put it into the primary and middle schools. This, in turn, will be put into student services. Its advantages and disadvantages can be discussed in any case". In contrast, $\mathrm{Y}_{21}$ noted a benefit of the project: "the Fatih project is encouraging underprivileged students and parents to use contemporary communication instruments". The problems that school managers noted about the Fatih project are shown in Figure 4.

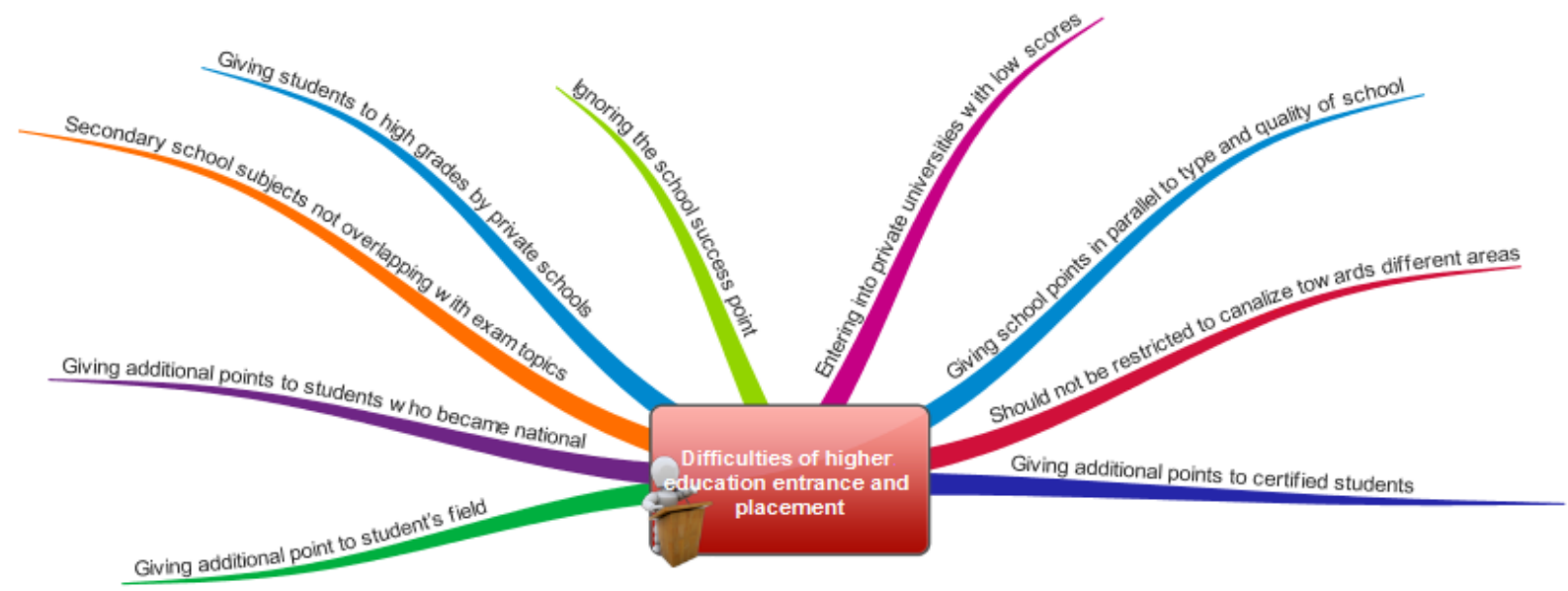

Figure 3. School managers' opinions about difficulties of higher education entrance and placement

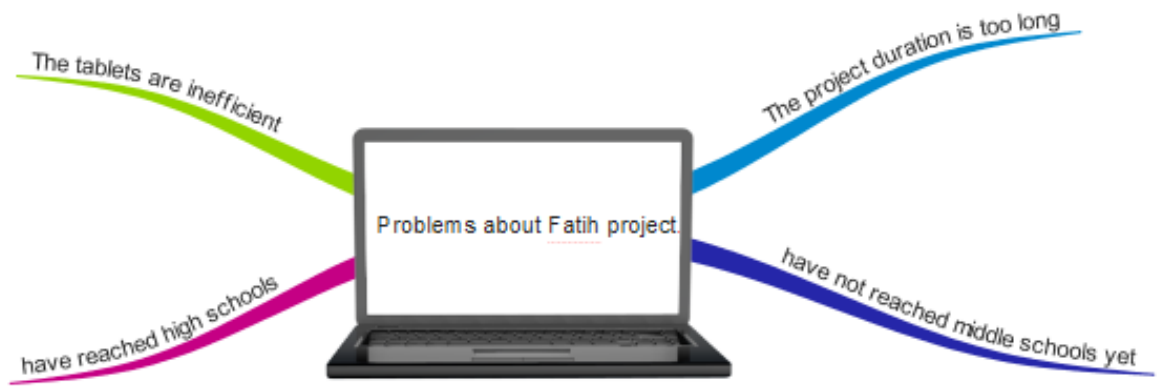

Figure 4. School managers' opinions about the problems of Fatih project 


\section{Discussion and Conclusions}

The first issue that school managers considered in terms of the $4+4+4$ education system was that encountered in question of the starting age for primary school. The majority of the participants stated that they disapproved of the primary school starting age and believed that the primary school should start at the age of 72 months and above. The reason why they think in this manner is that levels of students' physical, mental, emotional and psychological development vary according to socio-economic level and that difficulties been have experienced in implementation. They also stated that preschool education would be more effective for children below this age and that children of this age and above have achieved more qualified success. Dogan et al. [12] have supported these views by emphasising that one of the most highlighted negative effects of the $4+4+4$ education system on students is the reduction in the primary school starting age to the 60-66 month range. They noted that students of different age groups were educated in the same classrooms, that students in this group had compliance problems in the first grade, and that parents of younger students were always at school. Similarly Kandemir et al. [19] suggested that starting the first grade at the early age led to lack of self-confidence and failure in children, that students did not have self-care skills, that the age difference was a problem for older children, and the challenges of early age in the first grade, compelled the teacher. Mercan-Uzun and Alat [22] stated that there were students between 60 and 66 months of age in their classroom when generally analysed distribution of students of participants who expressed that they encountered with experience problems. Because they have been educated for seven to eleven years age children when they in universities. They assessed the basic cause of the problem as the attention span of students and the difficulty in concentrating.

The second issue addressed by the school managers was the division of elementary education into primary and middle school buildings. The majority of managers reached a consensus about separating primary and middle school buildings from each other. It was expressed that use of the same building and garden areas by students of different age groups led to problems such as using the same toilet, harassment, and negative influence that primary and middle school students had on each other. Memisoglu and Ismetoglu [21] have supported these views, indicating that problems arise such as different rush hours, transportation issues, and being unable to carry through the managers' responsibility to manage both institutions.

The third issue that school managers addressed was the regulation of compulsory education. The majority of participants preferred the older system, namely, the $5+3+4$ system rather than the $4+4+4$ education system. Some of their stated reasons were, for example, the problems that field teachers who are the teachers of several subjects, for example Mathematics, Science, Linguistic, English, etc., experienced with fifth grade students, (1) non-adaptation of fifth grade students to middle school, (2) finding the curriculum difficult for these students, (3) the rapid transition to a system without preparing the necessary infrastructure and syllabus and without creating teaching staff and specifying courses, (4) the difficulty in following up 8th grade students because a graduation certificate was not conferred on them, (5) the necessity to start vocational education in the middle school, (6) the impossibility of compulsory primary education for those who receive inclusive education and those with specific learning disability, (7) the lack of suitability at country level, the infrastructure needed for compulsory education and (8) the persistent occurrence of students who disrupt the school order.

A study by Bahtiyar-Karadeniz [2] revealed that $62.8 \%$ of participants did not support the system. Nevertheless, Dogan et al. [12] inferred that the $4+4+4$ education system provided positive opportunities for a variety of reasons. These included students being taught within their own age groups, students being given the opportunity to choose middle school based on their ability, and enhancing the quality of institutions due to competition in the transition to middle school since school choice are made during the transition to middle school. The fact that the majority of managers uphold the old system may also result from an inability to adapt to change. Argon and Ozcelik [1] stated that according to the teachers' views, school managers have only moderate qualifications for determining the need for change in schools, preparing the school for a period of change, and implementing and assessing change in the school. However, the vast majority of managers involved in the study have between 16 and 20 years of service or 26 years and above. In this regard, it can be said that there are elderly managers. As stated by Hamedoglu and Ozden [16], as managers grow older, and when they are considered to have a classical and authoritarian approach, it is understandable that they are not open to system modification.

The fourth issue that these school managers addressed was the gradual transition to compulsory education. The majority of the managers did not perceive a gradual transition to be appropriate. When the law was published it stated that aggrieved students at all levels due to all reasons such as staying students attending 5th, 6th, 7th and 8th classes at their schools, becoming some teachers vacant, leaving vacant teachers' class by asking for their appointment and appointing assignment or substitute teachers in the place of them brought about a set of problems. Similarly Ors et al. [24] inferred that two different levels of students receiving education in the same building would lead to conflict between the managers, and the workload of a single manager who manages the two levels has doubled and this is contrary to educational psychology and the $4+4+4$ education system.

The fifth issue that the school managers tackled was the necessity for the diversification of middle schools in a way that would appeal to different professional fields. The 
managers' opinions included opening middle schools together with Muslim religious sect leader and pulpit preacher middle school in vocational high schools, high school ages being tardy for vocational training and in this context, the need for vocational guidance by classroom teachers in primary schools and vocational training should start from the middle school ages.

The sixth issue that school managers addressed was related to teaching elective courses. They raised problems such as (1) greater numbers of hours for elective courses and greater diversity in lessons, (2) ignoring the characteristics of schools, equipment, qualifications and the situation of teachers related to the field, (3) the lack of related textbooks, failing to assess with marks and students choosing what they considered to be easy courses as a way of achieving a high mark. In this context, they have provided suggestions about planning weekly course hours, not exceeding 30 hours in middle schools and the reduction of course hours by combining some elective courses that are considered to be within the same field. As indicated in Memisoglu and Ismetoglu's (2013) research, the participants expressed that elective courses emphasized the difficulty of choosing a curriculum in elective courses, especially in non-group elective courses. Only students who took elective courses at the 5th Grade had problems in schools with transported education because they were longer than the exit time. Besides that in the findings of Cerit and et al.'s (2014) research, the school managers pointed out that the elective courses were excessive and not efficient enough.

The seventh issue that school managers considered was the entrance to higher education. They discussed the concern that the high school grade point average causes inequality, that the school success grade (as well as the diploma grade) should be considered in the transition to a university, that low-scoring students can enter into private schools through half and half scholarships and that this leads to unfair competition, that school subjects do not overlap with higher education examinations, that those who graduate from vocational high schools should be directed to graduate schools in line with the requirements and demands of the private sector, and, finally, that all registered students should participate in competitions

The final issue that the school managers addressed was Fatih project. They articulated their views that the project duration was lengthy, no standards had been set, and the project is progressing very slowly. They also stated their negative views about tablet computers and expressed positive opinions about interactive whiteboards in the schools. Furthermore, they stated that the project allows underprivileged students to utilize contemporary communication tools, and that the project has reached high schools but not middle schools in same region. As indicated in Ciftci, Taskaya and Alemdar's research (2013) participants' the biggest concern $(69 \%)$ of the process of applying the project was to tablet computers. Also they were worried about the reasons such as the use of tablet computers, breakdown, etc.

\section{Recommendations}

The following recommendations are based on the findings of this study:

(1) Children at and under 66 months of age should not be accepted for first grade, (2) children's development level and school maturity in all fields should be considered at and before 72 months, (3) primary and middle schools should be placed in separate buildings, (4) adaptation problems to middle school should be minimized by introducing adaptation studies for 5th grade students, (5) in-service training is organized for lower field teachers up to 5 th grade level and participation should be encouraged, (6) studies are undertaken into the issue of starting vocational orientation in middle school, (7) overall weekly course hours and elective course hours are reduced, the pool of elective course is narrowed, and elective courses are introduced according to the interests and needs of students, (8) vocational guidance in higher education entrance is regulated in accordance with the student's individual characteristics, school success points are added to placement scores. Constructive arrangements are made to receiving feedback on the Fatih project, (9) the quality and quantity of in-service training activities are improved so as to integrate tablets within education.

\section{Note}

*The abstract of this paper was presented at 8th World Conference on Educational Sciences (WCES-16), in Madrid on February, 04-06, 2016.

\section{REFERENCES}

[1] Argon, T., Ozcelik, N. (2008). The primary school administrators' competencies within the framework of administrating change. Journal of Mehmet Akif Ersoy Educational Faculty, 8(16), 70-89.

[2] Aykac, N. Kabaran, H. Atar, E. Bilgin, H. (2014). An evaluation of the teachers' opinions about the problems 1st grade students encountered as a result of $4+4+4$ application (The province of Mugla sample). Turkish Studies International Periodical For The Languages, Literature and History of Turkish or Turkic, 9(2), 335-348.

[3] Bahtiyar-Karadeniz, C. (2012). Opinions of teachers towards $4+4+4$ compulsory education system. Education Science Society Journal, 10(40), 34-53.

[4] Banathy, B. H. (1994). Designing education system. creating our future in a changing world. Reiguluth c m, Garfinkle $r \mathrm{j}$ eds. systemic change in education. Education technology publications, inc., Englewood cliffs, New Jersey. 
[5] Calıskan-Maya, I. (2006). A comparative analysis of the educational statistics of Turkey and EU countries in the EU accession process. Journal of Turkish Educational Sciences, $4(4), 375-379$

[6] Calp,S., Calp, M. (2015). 4+4+4 education system with perspective of field and primary teachers. Turkish Studies. International Periodical for the Languages, Literature and History of Turkish or Turkic, 10(11), 383-406

[7] Cerit, Y. Akgün, N. Y1ld1z, K. Soysal, M. R. (2014). Educational sciences research problems and solutions for the processing of the application of the new schooling system $(4+4+4)$ (City of Bolu Sample). Journal of Educational Sciences Research International E-Journal, 4(1), 59-82.

[8] Choi, A., Jerrim, J. (2015). The use (and misuse) of pisa in guiding policy reform: the case of Spain. document de traball de i'ieb 2015/6. Institut d'economia de Barcelona. From http://ssrn.com/abstract=2580141. Accessed 18 June 2016.

[9] Christensen, C., Horn, M. B., Johnson, C. W. (2008). Disrupting class: how disruptive innovation will change the way the world learns. Mc Graw Hill, Colombus, OH, US.

[10] Ciftci, S. Taskaya, S. M., Alemdar, M. (2013). The opinions of classroom teachers about Fatih Project. Elementary Education Online, 12(1), 227-240.

[11] Comertler, N., Kar, M. (2007). Economic and social determinants of the crime rate in Turkey: Cross-section analysis. Ankara Üniversity SBF Journal, 62(2), 1-17.

[12] Creswell, J. W. (2016). Qualitative Research Design: Qualitative research and research design based on five approaches, translator eds. M. Butun ve S. B. Demir. Ankara: Siyasal Publishing.

[13] De Wit, H. (2000). The Sorbonne and Bologna declarations on European higher education. International Higher Education. $18,8-9$.

[14] Demir, S. B. (2013). Evaluation of the new education system by social studies teachers. Educational Research and Reviews, 8(17), 1525-1532.

[15] Demir, S. B., Dogan, S., Pinar, M. A. (2013). Reflections of the new $4+4+4$ education system: Evaluation of the educational process in the fifth grades according to the field teachers' opinions. International Periodical for the Languages, Literature and History of Turkish and Turkic, 8(9), 10811098.

[16] Dogan, S., Ugurlu, C. T., Demir, A. (2014). Analysis of the " $4+4+4$ " education system's positive and negative effects on the school partners according to the opinions of administrator. Gaziantep University Journal of Social Sciences, 13(1), 115 138.

[17] Emrick, B. (2015). Forecasted changes in France's education system. prospect. Journal of international affairs at ucsd. From $<$ https://prospectjournal.org/2015/06/10/forecasted-changesin-frances-education-system/>. Accessed 18 June 2016.

[18] Epcacan, C. (2014). Opinions of primary and middle school teachers and administrators on the $4+4+4$ education system (Siirt sample). Journal of Social Sciences EKEV Academia, 18(58), 505-522.

[19] Epcacan, C. (2015). Elementary and middle school teachers' thoughts regarding the $4+4+4$ education system by some variables. International Periodical for the Languages, Literature and History of Turkish or Turkic, 10(3), 387-408.

[20] EURYDICE (2014). Finland: Reforms in school education $<$ https://webgate.ec.europa.eu/fpfis/mwikis/eurydice/index.ph p/Finland:Reforms_in_School_Education>. Accessed 19 June 2016.

[21] Guven, İ. (2012). The 4+4+4 School Reform Bill and the Fatih Project: Is It a Reform? Elementary Education Online, 11(3), 556-577.

[22] Hamedoglu, M. A., Ozden, E. (2015). Today's school manager's management comprehension examined in pilot of management theories. Sakarya University Journal of Education, 5(3), 7-26.

[23] Hershock, P. D., Mason, M., Hawkins, J. N. (2007). Changing education, leadership, innovation and development in a globalizing asia pacific. Springer publishing, Netherlands.

[24] Jakubowski, M., Patrinos, H. A., Porta, E. E., Wisniewski, J. (2010). The impact of the 1999 education reform in poland. The World Bank human development network education team policy research working paper 5263. From https://openknowledge.worldbank.org/ $=1 \mathrm{bitstream} /$ handle $/ 10986 / 3749 /$ wps5263.pdf?sequence $=1$ Accessed 18 June 2016.

[25] Kandemir, E. M., Sara, P., Akay, Y., Zemin, S. (2013). The opinions of 1 st grade teachers and parents as to 12 year compulsory education. Turkish International Journal of Special Education and Guidance \& Counseling, 2(2), 1-17.

[26] MEB. (2013). National Education Statistics Formal Education 2012-2013. Ankara: T.C. Ministry of National Education Presidency of Strategy Development Official Statistics Programme Publication. ISSN: 1300-0993.

[27] Memisoglu, S. P., Ismetoglu, M. (2013). The school administrators' conceptions concerning the system of $4+4+4$ in compulsory education. Journal of Research in Education and Teaching, 2(2), 14-25.

[28] Mercan-Uzun, E., Alat, K. (2014). First grade teachers' opinions about the implementation of $4+4+4$ education system and school readiness of students. Journal of Abant Izzet Baysal Education Faculty, 14(2), 15-44.

[29] MEXT. (2004). Reform of compulsory education. $<$ http://www.mext.go.jp/english/elsec/1303526.htm>. Accessed 19 June 2016.

[30] Ministry of National Education. (2017). $<$ http://fatihprojesi.meb.gov.tr/proje-hakkinda/> Accessed 23 May 2017.

[31] Ors, C., Erdogan, H., Kipici, K. (2013). The intermittent compulsory education system for 12 years from the viewpoint of administrators: The case of Igdir. Igdir University Journal of Social Sciences, 4(October), 131-154.

[32] Ozenc, E. G., Ozcan, Z. E., Guclu, F. ,Guney, E. K. (2016). Reflection of the 4+4+4 Education system on the fifth grade students: Teacher opinions. Elementary Education Online, $15(2), 560-580$.

[33] Pamuk, S. Çakir, R. Ergun, M. Yilmaz, H. B., Ayas, C. (2013). Teacher and student point of view tablet pc and interactive board use: FATIH project evaluation. Educational Sciences: Theory \& Practice, 13(3), 1799-1822. 
[34] Ploeg, F. V., Veugelers, R. (2007). Higher education reform and the renewed lisbon strategy: role of member states and the European commission. Cesifo working paper no. 1901. From $<$ http://www.ssrn.com/abstract $=962045>$. Accessed 18 June 2016.

[35] Sahlberg, P. (2006). Education reform for raising economic competitiveness. Journal of Educational Change, 7, 259-287.

[36] Shirley, D., Noble, A. (2016). The marathon of educational change. Journal of Educational Change, 17, 141-144.

[37] T.C. Official newspaper (2012). Number: 28261. From $<$ http://www.resmigazete.gov.tr/eskiler/2012/04/201204 11-8.htm>. Accessed 4 January 2016.
[38] Tangulu, Z., Cidaci, T. (2014). The problems faced by field teachers lecturing social sciences at 5 th graders. Journal of Kirsehir Education Faculty, 15(2), 227-242.

[39] Torney-Purta, J., Schwille, J., Amadeo, J. (1999). Civic education across countries: Twenty four national case studies from the IEA civic education project. The International Association for the Evaluation of Educational Achievement. Eburon Publishers. Delft, Netherlands.

[40] Wielemans, W. (2000). European educational policy on shifting sand? European Journal for Education Law and Policy, $4(1), 21-34$.

[41] Yildirim, A., Simsek, H. (2011). Research methods in social sciences. Ankara: Seckin Publishing. 